\title{
REPOSISI DAN PERAN BIROKRASI
}

\author{
${ }^{1}$ Firdaus, ${ }^{2}$ Susi Lawati \\ ${ }^{1}$ Pascasarjana Universitas Sjakyakirti, Email: drs_firdaus@unisti.ac.id \\ ${ }^{2}$ Pascasarjana Universitas Sjakyakirti, Email: uchisusilawati@unisti.ac.id
}

\begin{abstract}
The position and role of the state apparatus which is often referred to as the government bureaucracy is of concern, because most of the life of the state is regulated and determined by the government through the government bureaucracy. The position and role of the bureaucracy is interesting to discuss because the position and role have not been as expected. In general, the position of the government bureaucracy is always opposite between the rulers of the government / state and the people or the people they control. Where should the position of the bureaucracy be and what role should it play as long as the bureaucracy emphasizes the position of political power rather than socioculture, the bureaucracy becomes a servant to certain political interests so that services to the public are replaced by services to political power, so that every service is rooted in public service. always has the color of power and prioritizes the political interests served instead of the public interest as a whole. In line with the changes that have occurred in the order of government implementation and the development of community life in various aspects of life, the role of society in the life of the state has begun to be felt. Public demands began to affect the government work bureaucracy system. This situation in turn makes it increasingly possible to change the position and role of the public bureaucracy.
\end{abstract}

Keywords: Repositioning, Role, Bureaucracy

\begin{abstract}
ABSTRAK
Posisi dan peran aparatur negara yang sering disebut sebagai birokrasi pemerintah menjadi perhatian, karena hampir sebagian besar hidup bernegara diatur dan ditentukan oleh pemerintah melalui birokrasi pemerintah. Posisi dan peran birokrasi menjadi menarik dibicarakan karena posisi dan peran tersebut belum seperti apa yang diharapkan. Pada umumnya kedudukan birokrasi pemerintah selalu berlawanan antara penguasa pemerintah/negara dan rakyat atau masyarakat yang dikuasainya. Dimana seharusnya posisi birokrasi itu berada dan apa peran yang seharusnya dimainkan selama birokrasi lebih menekankan pada posisi power politik ketimbang sosial budaya maka birokrasi menjadi pelayan pada kepentingan politik tertentu sehingga pelayanan kepada publik diganti menjadi pelayanan kepada kekuatan politik, sehingga setiap pelayanan yang berakar pada pelayanan publik selalu berwarna kekuasaan dan mendahulukan kepentingan politik yang dilayani bukan kepentingan publik secara keseluruhan. Sejalan dengan perubahan-perubahan yang terjadi dalam tatanan pelaksanaan pemerintahan serta perkembangan kehidupan masyarakat dalam berbagai aspek kehidupan, maka peran masyarakat dalam kehidupan bernegara mulai terasa. Tuntutan masyarakat pun mulai terasa mempengaruhi sistem birokrasi kerja pemerintah. Keadaan seperti ini pada gilirannya membuat semakin dimungkinkan perubahan posisi dan peran birokrasi publik.
\end{abstract}

Kata Kunci: Reposisi, Peran, Birokrasi

\section{A. PENDAHULUAN}

Birokrasi merupakan suatu organisasi besar dengan ciri-ciri tertentu yang membedakan antara negara maju dengan negara berkembang. Walaupun mempunyai kesamaan ciri, tetapi diantaranya memiliki berbagai variasi yang membedakan antara Birokrasi negara maju dengan negara berkembang.
Terlepas dari variasi perbedaan antara negara maju dengan negara berkembang, birokrasi sebagai suatu organisasi yang digunakan pemerintah untuk dapat mengantisipasi terhadap tuntutan perubahan dan perkembangan lingkungan yang terjadi didalam masyarakat. Dimana proses perubahan tersebut sangat memberikan pengaruh terhadap birokrasi pemerintah. 
Dalam proses kehidupan berbangsa dan bernegara yang telah dilaksakan sebagaimana tercermin dalam pelaksanaan pembangunan selama ini dan dianggap sebagai suatu nilai yang benar oleh pemerintah, tetapi ternyata didalam perjalanannya menimbulkan berbagai penyimpangan-penyimpangan yang terjadi dalam pelaksanaan pembangunan.

Seiring dengan bergulirnya erareformasi ditanah air, mau tidak mau harus menyentuh birokrasi. Birokrasi di Indonesia berkembang menjadi birokrasi yang besar, boros, dan sarat dengan korupsi, kolusi dan nepotisme. Selain itu birokrasi juga dibebani oleh misi politik yaitu untuk menjaga serta mempertahankan kelangsungan suatu rezim. Melihat kenyataan demikian menuntut perlu dilakukannya reposisi dirinya menjadi lembaga yang netral.

Kritik terhadap birokrasi terjadi dimanamana, tidak saja dinegara berkembang akan tetapi juga termasuk dinegara maju. Di negara kita tampak terlihat dalam penyelenggaraan pemerintahan para aparat birokrasi banyak melakukan penyimpangan dalam menjalankan tugasnya. selain itu birokrasi menjadi mesin politik. Lembaga peradilan pun tidak dikembangkan sebagai lembaga yudikatif yang independen sehingga tidak mampu melakukan interpretasi hukum secara adil.

Birokrasi pada kenyataannya kurang adaptif terhadap tuntutan perubahan dalam proses pembangunan, sebagaimana dikatakan Bennis (1967) dalam Miftah Thoha (1991:52), birokrasi sendiri pada kenyatannya suatu kekuatan yang enggan terhadap perubahan. Namun selanjutnya Type ideal Weberian Birokrasi pemerintah bukanlah kekuatan politik, melainkan instrumen politik. Artinya birokrasi harus berfungsi sebagai agent bukan sebagai master. Birokrasi lebih banyak menekankan pada aspek administrastif dan teknik operasional dari politik. Birokrasi yang bukan merupakan kekuatan politik ini seharusnya dibebaskan pengaruh dan jalinan ikatan-ikatan politik yang sewaktu-waktu masuk ke birokrasi.

Keterlibatan birokrasi dan para birokratnya kedalam politik praktis merupakan jaringan kompleks antar elit politik dan para pejabat birokrasi. Persoalan politisasi birokrasi memang bukanlah persoalan baru di indonesia. Begitu kuatnya tarikan politik menyeret birokrasi sehingga intervensiintervensi politik selalu membayangi birokrasi. Masalah politisasi birokrasi adalah persoalan klasik, hanya persoalan ini bergeser pada persoalan siapa yang menjadi rezim penguasa yang memanfaatkan posisi birokrasi untuk melanggengkan kekuasaannya.

Pengelolaan sebuah pemerintahan idealnya memang harus dipisahkan dari ruangruang politik yang mencampurinya, meskipun sebuah pemerintahan dihasilkan dari proses politik, apalagi ketika sudah menyeret birokrasi kedalam kubu-kubu politik yang membuat birokrasi kontra produktif dari patron tugasnya sebagai lembaga yang netral yang berperan menjembatani kepentingan antara kepentingan negara dengan kepentingan masyarakat. Implikasi ini harus segera ditanggulangi, khususnya bagaimana mencari sistem yang dapat memperkecil peluang pemanfaatan birokrasi kedalam arena politik.

Selanjutnya selain dipergunakan sebagai fungsi instrumental bagi pencapaian tujuantujuan secara rasional dan efisien, juga dipergunakan sebagai instrumen kekuasaan untuk melakukan kontrol/pengendalian terhadap orang-orang dan berbagai lingkungan. Pada kedudukan dan fungsi yang terakhir ini terlihat adanya kecenderungan yang inherent dalam birokrasi kearah pemekaran kekuasaan atas lingkungan yang semakin meluas yang sering disebut sebagai "birokratisasi" dengan memperlihatkan ciriciri pemekeran kekuasaan birokrasi atas lingkungan yang semakin luas melampaui batas-batas tujuan awalnya dan regimentasi lingkungan-lingkungan itu oleh birokrasi. Dan dengan birokrasi cenderung menanggalkan peran instrumentalnya dan berubah menjadi tuan/penguasa, bukan hanya sebagai peran pelaksana public policy (Djojowadono, 1989).

Birokrasi pada konteks tersebut diatas tidaklah sama dengan istilah birokratisasi yang dikemukakan oleh Max Weber (1921, 1973) dalam evers (1990:227) yang diartikan semakin tumbuhnya penggunaan peraturan dan ketentuan-ketentuan yang dibangun secara formal dan rasional, kehidupan umum dan pribadi, terjadinya bentuk legalitas baru yang beralasan rasional meluasnya cara bertindak yang rasional dan pelembagaan semua faktor ini kedalam sebuah administrasi modern. 
Tatapi birokratisasi dimaksud adalah sebagai tumbuhnya aparat negara (Birokrasi parkinsonisasi) dan sebagai bertambahnya pengawasan yang bersipat birokratisasi secara umum.

Dengan melihat fungsi birokrasi yang semakin jauh meninggalkan misinya sebara birokrasi yang memihak kepada semua lapisan dalam upaya membawa kepentingan bangsa dan negara diatas kepentingan pribadi dan kelompok, maka birokrasi harus mampu mereposisi diri sebagai birokrasi publik yang diharapkan dapat membawa bangsa ini kedalam era baru menuju suatu bangsa yang besar dalam suasasana demokrasi dalam menghadapi era globalisasi.

\section{B. PEMBAHASAN}

Pentingnya reposisi dan peran birokrasi sebagai uapaya dalam rangkaian penyelenggaraan pemerintahan dan menunjang keberhasilan pembangunan. Upaya ini harus senantiasa dilihat sebagai suatu proses yang mengacu pada berbagai inovasi yang berkembang didalam masyarakat seperti ekonomi, sosial politik, ilmu pengetahuan dan teknologi.

Menurut Bennis dalam Miftah Thoha (1993), sedikitnya ada empat hal yang saling berkaitan mengapa posisi dan peran birokrasi harus berubah.

1. Adanya masalah-masalah kemanusiaan yang karena tingkat pendidikan semakin baik membawa tuntutan-tuntutan hidupnya semakin meningkat.

2. Adanya perubahan-perubahan yang cepat disekitar kita karena ilmu pengetahuan yang senantiasa berkembang, yang kadang-kadang tidak kita harapkan dan sulit diprediksi.

3. Adanya pertumbuhan-pertumbuhan yang kurang ditunjang oleh kemampuan organisasi pemerintah.

4. Kekomplekan teknologi modern yang menumbuhkan adanya spesialisasi dan aktivitas organisasi serta orang-orang nya dalam setiap kegiatan pemerintahan.

Apabila kita mencermati keempat yang dikemukakan oleh Bennis, maka di negara kita sekarang telah mengalami hal sedemikian untuk itu terjadinya perubahan kearah tersebut, maka birokrasi pemerintah harus merespon dengan cepat.

Reposisi dan peran Birokrasi merupakan suatu upaya untuk menghambat dan bahkan menghentikan lajunya peran dan pengaruh birokrasi yang selama ini amat sangat mendominasi dalam berbabai aspek kehidupan bangsa yang mengakibatkan posisi dan peran birokrasi memihak pada kepentingan penguasa. Reposisi dan peran birokrasi itu juga berkaitan erat dengan restrukturisasi birokrasi karena hal ini menyangkut bentuk ideal suatu birokrasi dalam melaksanakan misinya.

Ada tiga hal yang perlu diamati jika kita akan melakukan restrukturisasi dan reposisi birokrasi publik. Tiga hal itu merupakan kondisi yang mendasari proses perubahan dari tata pemerintahan lama (Orde Baru) ke tata pemerintahan baru (Pemerintahan Reformasi).

Pertama keinginan untuk menegakkan demokrasi secara baik, kedua perubahan sistem politik dari single majority ke multi partai, Ketiga terjadinya proses perkembangan teknologi informasi dan persaingan ekonomi global (Miftah Thoha, 2000).

\section{Penegakan Demokrasi Secara Baik}

Kehidupan politik kenegaraan Indonesia pada masa lalu dapat dikatakan sebagai suatu bureucratic polity (masyarakat politik birokrasi), hal ini terlihat karena kekuasaan dan partisipasi politik dalam pembuatan keputusan-keputusan penting hanya terbatas pada penguasa negara, terutama terletak pada militer dan para pejabat birokrasi. Sejalan dengan hal tersebut sebagaimana dikatakan oleh Jackson dan Pye (1978) dalam Sofyan Effendi (1987) ciri-ciri pokok masyarakat politik birokratik adalah :

1. Lembaga politik yang dominan adalah aparat birokrasi.

2. Lembaga-lembaga kepentingan lainnya seperti, parlemen, partai politik, dan kelompok-kelompok kepentingan semuanya lemah dan tidak mampu melakukan kontrol terhadap birokrasi. 
3. Masa diluar birokrasi secara politis dan secara ekonomis pasif, yang menyebabkan lemahnya peran partai politik, dan karenanya semakin memperkuat peranan birokrasi.

Dilain pihak dalam menegakkan demokratis secara baik masyarakat politik birokratik harus dapat ditekan atau dilenyapkan sehingga mampu menumbuhkan suasana demokratis dalam rangka mereposisi birokrasi publik.

Prinsip demokrasi yang paling mendasar adalah dengan meletakkan kekuasaan ditangan rakyat, bukan sebaliknya kekuasaan ditangan penguasa. Demokrasi adalah peoples power, kekuatan/kekuasaan rakyat (Sartono Kartodirdjo, 2000). Adanya kemerdekaan bagi seluruh rakyat untuk berserikat dan berkumpul sebagaimana diamanatkan oleh UndangUndang Dasar 1945 merupakan suatu indikator terlakasananya prinsip-prinsip demokrasi yang menghalalkan/menjunjung tinggi perbedaan pendapat antara satu sama lain.

Apabila dikatikan dalam konteks kelembagaan pemerintahan demokratis, maka prinsip-prinsip demokrasi sebagaimana tersebut diatas harus dapat dikembangkan. Sebagaimana dikatakan Miftah Thoha (2000), struktur kelembagaan pemerintah seharusnya tidak bisa lepas dari kontrol rakyat. Peranan rakyat dalam pemerintahan yang demokratis dilakukan ketika bentuk pemerintahan baik pusat maupun daerah akan disusun. Wujud dari peranan ini ialah bahwa setiap bentuk dan susunan lembaga pemerintah itu harus didasarkan pada Undang-Undang. Dan Undang-Undang inilah rakyat terlibat dalam mendesain dan menetapkan lembaga pemerintah baik dipusat maupun di daerah.

Dilain pihak Osborne dan Gaebler (1992) dalam bukunya Reinventing Government menyebutkan aparatur negara yang berdaya juga tumbuh dalam organisasi yang menumbuhkan iklim demokrasi partisipatif (Empowring Through democracy). Iklim demokrasi birokrasi yang demokratis menumbuhkan partisipasi dalam pengambilan keputusan dan bahkan dalam formulasi kebijakan yang secara langsung mempengaruhi pekerjaan mereka. Sementara partisipasi mengandung motivasi yang mempunyai efek positif meningkatkan kualitas kinerja aparatur. Partisipasi juga meningkatkan kualitas keputusan dimana keahlian nyata dan infromasi yang terbaik dialokasikan. Aparatur negara pada level yang paling rendah memiliki sumber-sumber kreatifitas dan kapabilitas untuk membuat dan memberi kontribusi yang bermanfaat bagi orgnaisasi birokrasi.

Penegakkan demokrasi secara baik yang merupakan hakekat dari demokrasi yang bernuansa pemerintahan dalah milik masyarakat. Hal ini dimaksudkan untuk menumbuhkan partisipasi masyarakat, bukan sebaliknya seperti yang terjadi selama ini partisipasi yang terjadi hanyalah berupa mobilisasi semata dari pemerintah. David Osborne dan Peter Plastrik dalam bukunya Memangkas Birokrasi (2000:322) Pemerintah milik masyarakat mengalihkan wewenang kontrol yang dimilikinya ketangan masyarakat. Masyarakat diberdayakan sehingga mampu mengontrol pelayanan yang diberikan oleh birokrasi. Dengan adanya kontrol dari masyarakat, pegawai negeri (dan juga pejabat terpilih, politisi) akan memiliki komitmen yang lebih baik, lebih peduli, dan lebih kreatif dalam memecahkan masalah.

\section{Perubahan Sistem Politik}

Elemen kekuatan politik pada suatu negara merupakan yang dianggap sebagai agent pembaharu adalah partai politik. Sekalipun disuatu negara banyak terdapat berbagai ragam partai politik, namun tidak jarang sedikit sekali partai politik yang mempunyai kekuasaan yang seimbang dengan pusat-pusat kekuasaan.

Pengalaman sejarah perpolitikan di Indonesia selama masa era Orde Baru yang melakukan penyederhanaan partai-partai politik (dengan dua partai politik dan Golongan Karya), maka sangat terasa elemen kekuatan politik melalui partai-partai politik yang ada hampir dan bahkan tidak pernah mengambil bagian pada posisi pusat kekuasaan. Pada masa ini sistem politik berlaku adalah sistem politik dengan kekuatan single Majority oleh Golkar, sehingga peran kontrol dari DPR maupun masyarakat terhadap jalannya birokrasi pemerintahan semakin tidak berdaya.

Bergulirnya era reformasi dan terbukanya katub demokrasi yang selama ini terjadi 
penyumbatan oleh suatu kekuatan otoriter, maka pada saat ini terjadi perubahan sistem politik dari sistem partai tunggal ke multi partai akan memberikan konsekwensi terhadap posisi dan peran birokrasi.

Politisasi birokrasi bukan merupakan fenomena baru di indonesia, dan bahhkan setelah memasuki era reformasi. politisasi birokrasi masih tumbuh dengan dengan subur karena struktur birokrasi dari pusat samapai ke daerah dimanfaatkan sebagai pondasi untuk untuk mempertahankan kekuasaan suatu rezim. Begitu kuatnya tarikan politik menyerat birokrasi sehingga intervensiintervensi politik terus terus membayangi birokrasi menjelang pemilukada, baik tingkat Provinsi maupun Kabupaten dan Kota di Indonesia.

Polarisasi birokrasi menjelang pemilukada terbagi menjadi dua bagian, disatu pihak adalah kelompok yang loyal. Kelompok tersebut memiliki konsistensi yang tinggi ketika mendukung calon secara terus menerus menghimpun dan mencari dukungan dari dalam birokrasi, sedang dilain pihak adalah kelompok oportunis adalah kelompok yang cenderung ambigu dalam memberikan dukungan, dikarena selalu menghitung untung rugi juga untuk menyelamatkan posisi dan jabatan dalam birokrasi. Dapat dibayangkan apabila birokrasi dihadapkan pada persoalan politis seperti ini, produktivitas dalam melakukan pelayanan publik akan terganggu. Akan ada dua gap yang melebar antar pejabat, karena situasi serba politis akan menjadi pertimbangan utama dalam mengelola birokrasi.

Perubahan sistem politik yang terjadi di indonesia diharapkan dapat mengembalikan posisi dan peran birokrasi dalam menjembatani anatara kepentingan negara (state) dan kepentingan masyarakat (society) sehingga netralitas birokrasi benar-benar dapat diwujudkan, sehingga memungkinkan birokrasi pemerintah dapat berlaku demokratis.

Sejalan dengan hal tersebut diatas sebagaimana dikatakan Miftah Thoha didalam Pidato Pengukuhan Jabatan Guru Besar, Birokrasi pemerintah bisa berlaku demokratis jika peran kontrol yang dilakukan oleh rakyat dijalankan secara maksimal, proporsional, konstitusional, dan bertanggung jawab. Didalam pemerintahan yang modern dan demokratis hampir tidak mungkin manajemen birokrasi pemerintahan bisa dijalankan tanpa kontrol dari rakyat (Miftah Thoha, 1992:2).

Peran kontrol dari rakyat dapat berjalan dengan baik apabila sistem politik yang dilaksanakan mampu menopang tumbuh dan berkembangnya iklim demokrasi. Demokrasi berarti pemerintahan rakyat, Abraham Lincoln mangatakan, Government of the people, by the people, for the people. Dalam sistem ini pemegang kekuasaan harus bertanggung jawab kepada rakyat dan pemerintah atas nama rakyat. Penguasa yang demokratis akan memandang kritik sosial sebagai bagian dari mekanisme politik, dan tidak akan menggunakan kekuasaannya untuk menekan kritik sosial (Muhadjir Darwin, 1996:181).

Sehubungan dengan konteks tersebut diatas, posisi dan peran birokrasi dalam sistem politik demokrasi adalah subordinate dari kepemimpinan politik dimana seluruh tindakannya ditujukan untuk melaksanakan semua aturan atau perintah dari politisi, dan tidak boleh pula berpihak kepada kepentingan sempit dari kelompok-kelompok tertentu dalam masyarakat. Birokrasi harus netral, berperan semata-mata sebagai mesin pemerintah yang melaksanakan tugas-tugas operasioanal atau administratif secara profesional.

\section{Perkembangan Teknologi Informasi}

Salah satu ciri dunia modern yaitu dengan berkembangnya Ilmu Pengetahuan dan Teknologi dengan sangat pesat. Perkembangan demikian merupakan suatu hal yang sangat positif bagi birokrasi untuk memahami berbagai aplikasi perkembangan yang merupakan suatu tantangan yang mempunyai implikasi dan harus dihadapi oleh birokrasi publik.

Beberapa implikasi dimaksud, sebagaimana dikatakan oleh Siagian, (1994:27-33), Pertama, dengan makin mudahnya kelompok masyarakat memperoleh akses pada pendidikan yang semakin tinggi. Kemampuan para warga masyarakat untuk 
haknya semakin tinggi. Pada gilirannya situasi demikian menuntut agar birokrasi lebih teliti dalam menetapkan berbagai ragam kebijaksanaan serta lebih transparan dalam pelaksanaannya. Kedua, makin banykanya warga masyarakat yang menyelesaikan tingkat pendidikan tinggi berakibat pada komposisi pencari kerja yang pasti mempunyai dampak terhadap rekrutmen, seleksi, dan penempatan tenaga kerja baru. Dengan situasi demikian implikasi yang ditimbulkan adalah perubahan pola penyeliaan (supervisi), karena harapan motivasi dan daya nalar dan pola interaksi antara pimpinan dan bawahan akan berbeda dengan situasi sebelumnya. Ketiga, berbarengan dengan perkembangan ilmu pengetahuan yang sangat pesat adalah perkembangan teknologi yang tidak kalah pesatnya. Yang jelas merupakan tantangan bagi birokrasi adalah perkembangan teknologi informasi. Keempat, penyelenggaraan pemerintahan negara, sebagai tugas pokok birokrasi, dan kian semakin lancar apabila dalam pelaksanaan berbagai fungsi manajerial di dalamnya tersedia informasi yang lengkap, mutahir dalam bidang komunikasi. Keseluruhan birokrasi merupakan organisasi yang besar dengan fungsi yang beraneka ragam yang sering bersifat spesialistik. Berangkat dari pendekatan kesisteman, keseluruhan birokrasi harus bekerja sebagai satu kesatuan yang bulat. Untuk itu diperlukan satu kesatuan persepsi, gerak dan langkah antara lain memerlukan koordinasi.

Selanjutnya bahwa salah satu tanda kemajuan zaman dan perubahan global ialah diberlakukannya cara kerja dalam suatu birokrasi dengan menggunakan teknologi informasi. Hal ini sebagaimana dikatakan oleh (Ashkenas, 1995 dan Lucas, Jr, 1996) dalam Miftah Thoha, (2000), cara kerja semacam ini kan menjadikan birokrasi tanpa batas (bondaryless organization). Selain itu birokrasi semacam ini akan banyak mengenalkan Paperless Organization.

Untuk itu dalam rangka reposisi birokrasi publik, kemajuan teknologi informasi harus dijadikan sebagai daya dukung di dalam melaksanakan tugas-tugas birokrasi sehingga birokrasi dapat menjebatani antara kepentingan pemerintah dengan kepentingan publik.
Birokrasi masa depan selain dihadapkan pada tantangan pemanfaatan teknologi informasi, juga harus mampu untuk memilih teknologi yang tepat bagi kebutuhan instansi yang bersangkutan sehingga pemanfaatan benar-benar efisien.

\section{PENUTUP}

Reposisi dan peran birokrasi publik disamping sebagai suatu upaya untuk membenahi pengalaman-pengalaman buruk birokrasi masa lampau juga untuk mempersiapkan birokrasi kedepan yang akan semakin rumit dan berat, baik karena perkembangan di dalam negeri sendiri maupun karena situasi regional dan global. Ketangguhan suatu birokrasi menghadapi tuntutan yang semakin berat dan meningkat itu, akan semakin meningkat apabila suatu birokrasi itu terbebas dari pengaruh suatu kekuatan didalam melaksakanan tugasnya.

\section{DAFTAR PUSTAKA}

Darwin Muhadjir, 1996, Demokratisasi Birokrasi di Indonesia, Di dalam Demokrasi Indonesia Kontemporer, Riza Noer Irfani (ed), PT. Raja Grafindo Persada, Jakarta

Darwin Muhadjir, 1998, Tinjauan Politik Birokrasi di Tengag Krisis Nasional, Makalah Seminar Krisis Nasional dan Perubahan Sosial, Hipiis Yogyakarta, 28 Oktober 1998.

Evers Dieter Hans, 1990, Kelompok Strategis, Studi Perbandingan Tentang Negara, Birokrasi, dan Pembentukan Klas Dunia, Yayasan Obor, Indonesia.

Effendi Sofyan, 1987, Birokrasi dan Administrasi Pembangunan, Makalah Seminar Birokrasi dalam Pembangunan, Yogyakarta.

Firdaus, Susi Lawati, 2019, Keterjangkauan Informasi dalam Pelayanan Publik, Jiask : Jurnal Ilmu administrasi dan Studi Kebijakan, Vo. 2, No. 1, 2019.

Kartodirdjo Sartono, 2000, Demokrasi Sudah Muncul Sejak Abad - 19, di Dalam Warta Pedesaan, Pusat Penelitian 
Pembangunan Pedesaan dan Thoha Miftah, 1993, Posisi dan Peran Kawasan, UGM, Tahun XVII, No. 5, Aparatur Negara dalam PJPT II, Mei 2000.

Nasikun, 1998, Мепијu Pembangunan Manajemen Pembangunan No,2/1 1993.

Pluralisme, Lokalisme dan Kembalinya Komunitas Politik, Makalah Seminar Krisis Nasional dan Perubahan Sosial, Hipiis, Yogyakarta, 28 Oktober 1998.

Osborne. D dan GAebler. T, 1996, Mewirausahakan Birokrasi, Pustaka Binaman Presindo, Jakarta.

Osborne. D dan Plastrik. P, 2000, Memangkas Birokrasi, Lima Strategi menuju Pemerintahan Wira Usaha, Penerbit PPM, Jakarta.

Rakhmat Rakhmat, Firdaus Firdaus, 2019.

Dinamika Implementasi Kebijakan Penanggulangan Kemiskinan di Indonesia, JIASK: Jurnal Ilmu Administrasi dan Studi Kebijakan, Vol. 1, No. 2, 2019. -, 1991, Beberapa Aspek Kebijakan Birokrasi, PT Media Widya Mandala, Yogyakarta.

1999, Demokrasi Dalam Birokrasi Pemerintah Peran Kontrol Rakyat dan Netralitas Birokrasi, Pidato Pengukuhan Jabatan Guru Besar pada FISIPOL UGM, 18 Mei 1999.

-------------, 2000, Restrukturisasi dan Reposisi Birokrasi Publik, Makalah Seminar asional, Profesionalisme Birokrasi dan Peningkatan Kinerja Pelayanan Publik, Yogyakarta.

Zamzam, F., \& Aravik, H. 2016. Manajemen SDM Berbasis Syariah, Bogor: CV. RWTC Success.

Siagian. P. Sondag, 1994, Patologi Birokrasi, Analisis, Identifikasi, dan Terapnnya, Ghalia, Indonesia. 
